\title{
SZEMLE
}

\section{A Chlamydomonas zöldalga nemzetség algáinak szerepe a biotechnológiában és helyük a zöldalgák rendszerében}

\author{
KATONA Szabina ${ }^{1}$, MOLNÁR Zoltán ${ }^{1}$ és ÖRDÖG Vince ${ }^{1,2}$ \\ ${ }^{1}$ Nyugat-magyarországi Egyetem, Mezőgazdaság- és Élelmiszertudományi Kar, \\ Növénybiológiai Intézet, 9200 Mosonmagyaróvár, Lucsony u. 15-17.; \\ szabina.katona@gmail.com \\ ${ }^{2}$ University of KwaZulu-Natal, School of Biological Sciences, Pietermaritzburg Campus, \\ 3209 Scottsville, Private Bag X 01, South African Republic
}

Elfogadva: 2016. február 25.

Kulcsszavak: biotechnológia, Chlamydomonas, filogenetika, polifázikus megközelítés, taxonómia, zöldalgák.

Összefoglalás: A Chlamydomonas az egyik legnagyobb zöldalga nemzetség több mint 800 leírt fajjal. Megközelítőleg 400 törzsük áll rendelkezésre törzsgyüjteményekben és alkalmazható kutatási célokra. A Chlamydomonas nemzetség sokoldalú gyakorlati jelentőségére utal, hogy modellszervezetként olyan tudományterületeken alkalmazzák, mint a fotoszintézis kutatás, a genetika, az UV-rezisztencia kérdései, a biogáz- és biodízel-termelés lehetőségei, a hormonkutatás, a mezőgazdaság és a gyógyszerkutatás. A Chlamydomonas taxonokat hagyományosan életciklusuk vegetatív szakaszában, morfológiai jellemzőik szerint osztályozzák. Az egysejtủ szervezeteket magába foglaló nemzetség alapvető jellemzője a két egyenlő hosszúságú ostor és a sejt térfogatának mintegy felét kitevő kloroplasztisz, amely egy vagy több pirenoidot tartalmaz. Az 1990-es évek óta, a molekuláris markerek filogenetikai elemzésben való alkalmazása bebizonyította, hogy a morfológiai megközelítés nem kielégítő a legtöbb zöldalga, így a Chlamydomonas nemzetség esetében sem. Napjainkra kiderült, hogy a nemzetség polifiletikus, ezért alapos felülvizsgálatra van szükség, amelyre a legújabb irányvonal, a polifázikus megközelítés kínál lehetőséget. Utóbbi olyan különböző eljárásokat egyesít magában, mint a morfológiai, citológiai, ultrastrukturális és molekuláris biológiai elemzések. A hagyományos taxonómiát alkalmazó morfológusok több mint 800 Chlamydomonas fajt jegyeznek, de a polifázikus megközelítés alkalmazásával ez a szám minden bizonnyal a töredékére, 100-150 taxonra fog csökkenni.

\section{Bevezetés}

A zöldalgák az eukarióta fotoautotróf élőlények nagy és sokszínű csoportját alkotják, kezdve az egysejtűektől a többsejtű formákig (BELLINGER és 
SIGEE 2010). Zöldalgákat a világon mindenütt találhatunk beleértve olyan élőhelyeket is, mint az északi-sarki és az antarktiszi régiók, az óceánok és az édesvizű tavak, az örök jég és hó felszíne, valamint a különféle talajok a mérsékelten nedves területektől egészen a száraz területekig (PRÖsCHOLD és LELIAERT 2007). Zöldalgák olyan életközösségben is megtalálhatóak, mint a zuzmók, az egysejtüek és likacsoshéjúak, vagy parazitákként a trópusi növényeken. Egyes becslések szerint legalább 600 nemzetségük és 10000 fajuk létezik (NoRTON et al. 1996).

Alapvető ökológiai funkciójuk a napenergia kémiai energiává való átalakítása. Számos tulajdonságuk van, mely a víz-, talaj- és növényrendszereket befolyásolja és lehetővé teszi gyakorlati felhasználásukat. Extracelluláris poliszacharidok (EPS), például alginátok, agarok, karragének, fukodiánok termelése révén az élelmiszer- és gyógyszeriparban, de más iparágakban is elterjedt a használatuk (Misurcova et al. 2012). További gyakorlati jelentőségük, hogy növényi növekedést szabályozó (PGR: Plant Growth Regulator, BARSANTi 2006), illetve antimikrobiális anyagokat is kiválasztanak a környezetbe (PRAKASH et al. 2011).

A Chlamydomonas az egyik legnagyobb zöldalga nemzetség több mint 800 leírt fajjal. Megközelítőleg 400 törzs áll rendelkezésre törzsgyüjteményekben és alkalmazható kutatási célokra (PRösCHOLD et al. 2001). Hagyományosan a Chlamydomonas nemzetség tartalmazza az összes, két azonos hosszúságú és egymás szomszédságában található ostoros egysejtü zöldalgát. A nemzetség képviselői egyetlen kloroplasztiszt tartalmaznak, egy vagy több pirenoiddal (ETTL 1976). A Chlamydomonas nemzetség sokoldalú gyakorlati jelentőségére utal, hogy modellszervezetként olyan tudományterületeken alkalmazzák, mint a genetika, a fotoszintézis kutatás, az UV-rezisztencia kérdései, a biogáz- és biodízel-termelés lehetőségei, a hormonkutatás, a mezőgazdaság és a gyógyszerkutatás. A jelen szemlecikk célja ezen algacsoport szerepének és felhasználási lehetőségeinek áttekintése a természettudományos alapkutatás és a biotechnológia területén, valamint taxonómiai helyük bemutatása a rendszertani kutatások legfrissebb eredményei alapján.

\section{A Chlamydomonas nemzetség algáinak biotechnológiai kutatása}

\section{A Chlamydomonas reinhardtii Dangeard, mint modellorganizmus}

A Chlamydomonas reinhardtii Dangeard széles körben használt laboratóriumi zöldalga. A hajtásos növényekkel összehasonlítva jelentős előnye, hogy egysejtü, haploid és szervetlen sókból álló tápközegben is szaporodik, továbbá alternatív szénforrásként acetátot felhasználva, sötétben is képes szaporodni (FUNES et al. 2007). Mint modellszervezetet, intenzíven használták és használják a fo- 
toszintézis, a légzés, a nitrogén anyagcsere és a csillómozgás tanulmányozására. Rövid életciklusa lehetővé teszi, hogy a genetikai elemzések hatékony eszköze legyen. Az elmúlt 25 évben jelentősen megnövekedett a molekuláris genetikai kutatások száma az algák esetében is. Ennek kiemelkedő példája a Chlamydomonas genom projekt, ami a $C$. reinhardtii molekuláris feltérképezéséből, így a teljes génállományának megismeréséből állt (PRÖsCHOLD és LELIAERT 2007).

A C. reinhardtii a növényi és állati sejtekben lejátszódó folyamatok vizsgálatához egyaránt modellként szolgál. Kiválóan alkalmas az algaszaporodás, a fotoszintetikus pigmentek és klorofill fluoreszcencia változásainak, valamint az oxidatív stressz hatásainak tanulmányozására. A C. reinhardtii-t a lipidanyagcserekutatás területén is modellként tartják számon (FAN et al. 2011). A zsírsav-bioszintézis az algasejt kloroplasztiszában és az endoplazmatikus retikulumban (ER) megy végbe, épp úgy, mint a hajtásos növényeknél (ZHANG et al. 2011). BERTALAN et al. (2007) ürkutatási kísérletekben a $C$. reinhardtii II. fotokémiai rendszerének stressztürését vizsgálta. LEóN és GALVÁN (1997) kimutatták, hogy a C. reinhardtii magas sókoncentrációjú környezetben $(200 \mathrm{mM} \mathrm{NaCl})$ glicerint termel, ami ozmózisszabályozó másodlagos anyagcseretermék.

A C. reinhardtii vizsgálata alapjaiban véve mozdította elő tudásunkat a fotoszintézis területén (kloroplasztisz-biogenezis, szerkezeti és funkciós kapcsolatok a fotoszintetikus komplexekben, környezeti szabályozás). A nemzetség törzsei jó választásnak bizonyultak a hajtásos növényekben lezajló fotoszintézisért felelős gének százainak megértéséhez is (DENT et al. 2001). Ezek egyike például a Tla1 gén, amely Tetali et al. (2007) vizsgálatai szerint a $C$. reinhardtii fénygyüjtő klorofillantennájának kialakításáért felelős.

Az ultraibolya sugárzás okozta stresszt számos egysejtü alga és vízi élőlényegyüttes esetében vizsgálták. Egyes eredmények azt mutatják, hogy a legkülönfélébb eukarióta élőlényekhez hasonlóan, az algákban is működik egy olyan jelátviteli útvonal, amelyen keresztül ún. ellenőrzési pontok aktiválásával képesek DNS-károsodás esetén a sejtciklus továbbhaladásának megakadályozására. Elsősorban a $C$. reinhardtii UV-sugárzás okozta DNS-károsodásra érzékeny uvs11 mutáns törzsével folytatott vizsgálatok engednek erre következtetni (SLANinová et al. 2003).

\section{Élettani kutatások Chlamydomonas fajokkal}

A Chlamydomonas eugametos Moewus és C. moewusii Gerloff fajok a DNSanalízis alapján távoli kapcsolatban állnak a $C$. reinhardtii fajjal (BUCHHEIM et al. 1990). Genetikai feltérképezésük már a kezdeti szakaszban abbamaradt, ugyanis a két faj a $C$. reinhardtii fajhoz képest csak korlátozott számú mutánssal rendelkeznek (HARRIs 2009). Mindkét faj kloroplasztiszát LEMIEUX et al. 
(1985) kiterjedten vizsgálták mind genetikai, mind molekuláris biológiai tekintetben. Gowans (1976) a Chlamydomonas eugametos auxotróf mutánsait vizsgálta. Ezek olyan mutánsok voltak, amelyek fejlődésre csak bizonyos készen kapott anyagok (aminosavak, vitaminok) felvételével képesek (GowANs 1976).

A Chlamydomonas monoica Strehlow homotallikus, azaz magával vagy egy hasonló törzzsel kereszteződni képes szervezet. Ezzel szemben heterotallikus élőlény az, amely önsteril és kompatibilis partnert kíván a reprodukcióhoz. VANWINKLE-SWIFT et al. (1998) e faj szexualitásának genetikai kontrollját, a zoospórák képződését és azok falának szerkezetét vizsgálták. A Chlamydomonas geitleri Ettl és C. noctigama Korschikoff szintén homotallikus fajok. FRANCOIs és RoBINSON (1988) ezek életciklusát, szaporodását (NECAs et al. 1986) és herbicidekre adott válaszát tanulmányozták.

REMIAS (2010) vizsgálatai a hó vagy jég felszínén is tömegesen elszaporodni képes és vörös elszíneződést okozó Chlamydomonas nivalis Wille pigmentösszetételére és fotoszintézisére irányultak megnövekedett UV-sugárzás mellett. Kimutatta, hogy képes tolerálni a rövid időtartamú, ismétlődő UV-B besugárzást. Fotoszintézise egy időre ugyan gyengül, de sejtválaszként karotinoidokat termel, ami pajzsként védi a zöld színtesteket. DUVAL et al. (2000) vizsgálatai fenol vegyületeket, illetve antioxidáns anyagokat mutattak ki a $C$. nivalis fajban UVsugárzás hatására. A C. nivalis kiemelkedően magas karotinoid tartalma nagyban hozzájárul a káros napsugárzással szembeni védekezéshez (BIDIGARE et al. 1993), szükségtelenné téve UV-abszorbeáló vegyületek szintézisét. Említésre méltó a „zöld hó” jelenség is, amelyet a sarkköri C. balleniana Kol et Flint és a Yellowstone Nemzeti Parkból izolált C. yellowstonensis Kol idéz elő. Ez utóbbi előfordul a Kaukázusban is, ahol fagypont alatt tenyészik és mozogni is képes (KoL és Flint 1968). Dolmi et al. (2013) szerint a sarkköri $C$. raudensis Ettl jó modell a hidegben, szélsőséges körülmények között végbemenő fotoszintézis megértéséhez. A C. altera Skuja szintén kriotoleráns (fagytürő) faj (HARRIs 2009).

A környezet savasodása miatt olyan fajok kerültek előtérbe, mint a Chlamydomonas acidophila Negoro vagy a C. sphagnophila Pascher. Ezek az algák képesek belső pH-szintjüket közel semleges szinten tartani, míg a közeg pH-ja, amelyben növekednek, 1,7 és 2,5 között változik (VIsviki és PALladino 2001). Visviki és SANTiKul (2000) a Chlamydomonas applanata Pringsheim fajt vizsgálták, amely 3,4 és 8,0 pH-érték között tolerálja környezete kémhatásának változását, növekedési optimuma pedig 7,4 pH-nál van.

Említést érdemelnek a halotoleráns (sótürő) fajok is, mint például a Chlamydomonas reginae Ettl et Green, a C.pulsatilla Wollenweber, a C. angulosa Dill vagy a $C$. provasolii Lee. Ezeknek a fajoknak a génexpresszióját úgy vizsgálták, hogy közben ozmotikus folyamatoknak és metabolikus stressznek vetették alá őket (TAKeda et al. 2003, TAmoi et al. 2005, TANAKA et al. 2004). 
A biodízel-, a biogáz- és a hidrogéntermelés lehetőségei

Ma már széles körben ismert az a tény, hogy algákból bioüzemanyagokat lehet előállítani. Jelenleg a legtöbb becslés, ami az algák bioüzemanyag-termelési potenciáljára vonatkozik kisléptékű kísérleti adatokból ered. A nagyobb méretű szabadtéri létesítmények vizsgálata is megkezdődött, ahol az algákkal foglalkozó cégek elsősorban a biodízel-termelés hatékonyságát elemzik. Mindemellett, több alapkutatásra volna szükség, hogy jobban megértsük a lipidtermelés biológiai hátterét, és szert tegyünk az optimalizált bioüzemanyag-előállítás képességére (DUBINI 2011).

A mikroalga-termesztést a megvilágítás költségei korlátozzák, ugyanis ez a legdrágább eleme a tenyésztésnek, különösen, ha az zárt foto-bioreaktorban történik. Kıм et al. (2014) egy Chlamydomonas törzzsel végzett kísérleteik során periodikus (villanófényes) megvilágítást alkalmaztak, amivel 63\%-os energiamegtakarítást értek el, anélkül, hogy ez a szaporodás vagy a lipidtermelés rovására ment volna. Bár a napfény lényegében ingyenes fényforrás a nyílt algatermesztő rendszerekben, a foto-bioreaktorok messze felülmúlják a nyílt tavi rendszerek termelékenységét, és a tenyészetek szennyeződése is könnyebben elkerülhető (UGWU et al. 2008). Azonban a mikroalgák tömegtermesztésének széles körben történő elterjedését jelentősen korlátozzák olyan problémák, mint a sürü sejtszuszpenzió okozta fénylimitáció, a monokultúra nehéz fenntartása (vírusok, gombák okozta fertőzés), és más környezeti tényezők szabályozásának hiánya (CHISTi 2007, Hu et al. 2008). A heterotróf módon, sötétben is szaporodó Chlamydomonas kultúrák költséghatékony, nagy léptékű alternatív termesztési módszert jelenthetnek, mert egyedüli szén- és energiaforrásként hasznosítják a szerves szénvegyületeket. Ezzel a termesztési eljárással kiküszöbölhetők a leggyakoribb, fotoautotróf rendszerekben előforduló problémák, de nagyobb sejtsűrüség és termelékenység is jellemzi (Rodolfi et al. 2009).

A mikroalgák által termelt lipidek/zsírsavak a biodízel alapanyagai (olyan vegyületek, amelyekből biokémiai folyamatok során jön létre a végtermék). A mikroalgákból származó nyereséges biodízel-termeléshez ismernünk kell a lipid-bioszintézis folyamatát. Emiatt kezdték vizsgálni a $C$. reinhardtii lipidanyagcseréjét (CAGNON et al. 2013). Az algákból előállított biomassza három fontos komponenst tartalmaz: szénhidrátokat, fehérjéket és lipideket/természetes olajokat. Ez utóbbi miatt kerültek a zöldalgák a bioüzemanyag-termelés látókörébe (CHISTI 2007). Gyorsan szaporodnak, általában 24 óránként megduplázzák tömegüket, de egyes képviselőik akár 3,5 óránként is osztódhatnak (SPOLAORE et al. 2006). DENG et al. (2014) kutatásai rámutattak arra, hogy az algasejtek olajtartalmát a $C r P E P C 1$ gén szabályozza.

A mikroalga-biomasszával való biogáztermelésre vonatkozóan kevés kísérleti adat van, pedig története több mint 50 évre nyúlik vissza, amikor Scenedesmus 
sp. és Chlorella sp. zöldalgák keverékét használták anaerob fermentorok táplálására (WIRTH 2014). A legjobb biogázhozamot a Chlamydomonas reinhardtii szubsztrátként való felhasználásakor sikerült elérni (MUSSGNUG et al. 2010). Megfigyelték, hogy a biogázhozam összefüggésben van az alga sejtfalának vastagságával, valamint a szubsztrát minőségével. Az algabiomassza szárítása 20\%al csökkentette a gázhozamot.

A Chlamydomonas törzsek képesek hidrogén termelésére. Számos kutató dolgozott a fotobiológiai hidrogénprodukció tanulmányozásán (MELIS et al. 2000, GHirardi et al. 2005), a végbemenő folyamatok és enzimek jellemzésén (Greenbaum 1982, GHirardi et al. 2009). Laboratóriumban, tartós fotobiológiai hidrogéntermelést csak a fotoszintetikus $\mathrm{O}_{2}$-termelés folyamatos gátlásával sikerült elérni, például a kén megvonásával. Ez a módszer lehetővé tette a folyamatos hidrogéntermelést négy napon keresztül (GREENBAUM 1988). A Chlamydomonas törzsek hidrogéntermelésre sötét fermentáción keresztül is képesek (GFELler és GibBs 1984). Anaerob fermentációs körülmények között a piruvát oxidációja a piruvát-ferredoxin-oxidoreduktázokkal (PFR) történik. Ez $\mathrm{CO}_{2}$-ot, acetil-CoA-t és redukált ferrodoxint (FDX) eredményez, ami elektront szállít a hidrogenáz enzimnek, hogy hidrogént termeljen (GHIRARDI et al. 2009).

\section{A gyógyászati alkalmazás lehetőségei}

A Chlamydomonas reinhardtii tenyészetekre „fehérje-bioreaktor”-ként is tekinthetünk, ugyanis az általuk termelt rekombináns fehérjék gyógyászati célokat szolgálhatnak (MANUEL et al. 2007). A rekombináns DNS-technológia kidolgozása megteremtette az alapjait annak, hogy a terápiás célra használandó fehérjéket egyszerủ mikroorganizmusok által, a fermentáció jól ismert alapelveit alkalmazva termeltessék (MAYFiELd és FrAN KLIN 2005). A rekombináns fehérjéket három csoportra oszthatjuk: monoklonális antitestek, vakcinákhoz használt antigének és terapeutikus fehérjék. A monoklonális antitesteknek a rákkutatás területén van jelentős szerepük (TRAN et al. 2009). Az antigéntartalmú vakcinák antitest termelésére serkentik a szervezetet, amely fokozza az immunrendszer működését. A terapeutikus fehérjék betegségek kezelésére szolgálnak (ilyen fehérje például az inzulin a cukorbetegség esetében) (Solís et al. 2011).

\section{A mezőgazdasági alkalmazás lehetőségei}

A víz mellett a talaj a legfontosabb élőhely az algák, így a Chlamydomonas taxonok számára is (ZENOVA et al. 1995). Mezőgazdasági területeken azért fontosak, mert potenciális nitrogén- és szénforrásként szolgálnak más élőlényeknek. A talaj termőképessége általában javul a talajalgák által termelt szerves anyagoktól. A hajtásos növények számára növekedést elősegítő anyagokat vá- 
lasztanak ki, például hormonokat, vitaminokat, aminosavakat és szerves savakat. Jelenlétük stabilizálja a talaj felszínét, és ebből adódóan csökkentik az eróziót (EvAns és JoHANSEN 1999, Hu et al. 2004). Néhány talajalga által előállított poliszacharid növeli a talaj aggregációját és vízmegtartó képességét. A talajokon és vízi élőhelyeken kívül, Chlamydomonas törzseket izoláltak még szennyvíztározókból, hóból, erdőkből, sivatagokból, tőzegtelepekről, nyirkos falakról, sérült szilfa nedvéből, vulkanikus szigetek mesterséges tavaiból, ágymatracban lévő porból, tetőcserepekről, vaddisznódagonyákból és levegőből 1 km-es magasságból (HARRIs 2009).

A Chlamydomonas zöldalga ostorai segítségével vizes közegben úszó, a talajban pedig kúszó mozgásra képes. Amikor ostorai szilárd közeggel érintkeznek (például talajszemcsével), az ostorvégekkel odatapad (BLoodgood 1990). Az Egyesült Államokban sikerrel alkalmaztak zselés állagú zöldalgákat (Chlamydomonas, Asterococcus) mezőgazdasági talajok szerkezetjavítására (METTING és RAYBURN 1983, BARCLAY és LEWIN 1985, MetTing 1987). A felszíni talajréteg poliszacharidtartalma jelentősen nőtt, és bár szabadföldi körülmények között az algaszaporodás csak megfelelő vízellátottság mellett tartható fenn, a zselés állagú zöldalgák és cianobaktériumok talajkondicionálóként történő felhasználása ígéretesnek bizonyult (MetTing 1988, Zimmerman 1992, FALCHini et al. 1996).

A gyorsan szaporodó talajalgák poliszacharidjai fontos talajmegkötő és nedvességtároló hatásuk mellett a foszfát-ionok és mikroelemek hozzáférhetőségének javításával, továbbá a nitrogén tárolásával és lassú felszabadításával járulnak hozzá a talajok biotrágyázásához (PAINTER 1993). Az évenkénti talajoltás a Chlamydomonas mexicana Lewin zöldalgával enyhén növelte a talajok szénhidráttartalmát az USA-ban (MEtTing és RAYBURN 1983). ViSviki és PALLADiNo (2001) a C. acidophila Negoro fajon végzett szaporodási és sejttani vizsgálatokat savas körülmények között, ugyanis ez pH 2,0 körül is szaporodik, így elképzelhető savas talajokon történő alkalmazása.

Analitikai mérések eredményei alapján napjainkra nyilvánvalóvá vált, hogy a zöldalgák növényi hormonokat termelnek (ÖRDöG et al. 2006), amelyek biológiai hatásuk miatt speciális növénykezelésekre használhatók. Alkalmasak a transzspiráció csökkentésére, fokozzák a terméskötődést, növelik a levelek klorofilltartalmát, a termés fehérjetartalmát, valamint serkentik a gyökér- és hajtásfejlődést (STIRK et al. 2013a, 2013b). A hormontermelő algák szuszpenziójával kezelt növényeknél javul a termés minősége, nő a termés hozama, sőt növényvédelmi problémákat orvosolhatunk vele (ÖRDÖG et al. 2006). JäGER et al. (2010) kukorica (Zea mays L.) biotesztekkel igazolta a mikroalgák citokinin- és auxinszerü hatását. STIRK et al. (2013a) endogén auxinok és citokininek menynyiségét határozták meg 24 axenikus mikroalga törzsből. STIRK et al. (2013a) két auxin alakot, IAA-t és az IAM-et mértek az említett mikroalga törzsekben. 
Tizenkilenc törzsben az IAA akár tízszer nagyobb koncentrációban volt jelen, mint az IAM. Néhány törzsben, pl. az MACC-772 C. reinhardtii-ban az IAA nagyon nagy koncentrációban (közel $40 \mathrm{nM} \mathrm{g}^{-1}$ szárazanyag) fordult elő, és az IAA:IAM aránya (214:1) is nagyon magas volt. STIRK et al. (2013b) endogén gibberellineket és brasszinoszteroidokat is kimutattak ugyanennek a 24 zöldalga törzsnek a 4 napos tenyészeteiben. Ez utóbbi az első közlemény az endogén gibberellinekről, amelyeket sikeresen detektáltak mikroalgákban. A vizsgált törzsekből 18-20 gibberellint mutattak ki. Két brasszinoszteroidot, a brasszinolidot és a kasztaszteront az összes törzsben megtalálták. Általában a brasszinolid a kasztaszteronnál magasabb koncentrációban fordult elő.

\section{A Chlamydomonas nemzetség helye az algák rendszerében}

A Chlorophyta divízió legnagyobb csoportja a Chlorophyceae osztály, amely körülbelül 350 nemzetséget, köztük a Chlamydomonas genust, és mintegy 2500 fajt foglal magába. (Pulz és Gross 2004). A Chlamydomonas nemzetséget (görögül: chlamys vagyis köpeny, palást, illetve monas, ami magányosat jelent) Ehrenberg nevezte el (EHRENBERG 1833, 1838), amely valószínüleg egyezik az 1786-ban leírt ostoros Monas-szal (ETTL 1976).

A Chlamydomonas nemzetség a Chlamydomonaceae családba tartozik (UMEN et al. 2011). A nemzetség több mint 800 fajt foglal magában, de mára felismerték, hogy polifiletikus (jellemvonásaik hasonlóak, azok több ősre vezethetők vissza, a hasonló tulajdonságok egymástól teljesen függetlenül jöttek létre a párhuzamos evolúció során), így a nemzetségnek alapos felülvizsgálatra van szüksége (STERN et al. 2009). A nemzetség jellegzetes és legjobban tanulmányozott képviselőjének, a $C$. reinhardtii-nak a rendszertani helye FREY (2015) szerint a következő:

Birodalom: Eukaryota

Ország: Viridiplantae

Törzs: Chlorophyta

Osztály: Chlorophyceae

Rend: Chlamydomonadales

Család: Chlamydomonadaceae

Nemzetség: Chlamydomonas

\section{A Chlamydomonas nemzetség rövid jellemzése}

A Chlamydomonas taxonok rendszertani besorolására irányuló kezdeti próbálkozások a sejtek színét és fénymikroszkópos morfológiáját vették alapul. Bár ezek továbbra is fontos jellemzők, más szempontok, mint például a fénygyüjtő 
pigmentek típusai, sejtfal alkotóelemek és a raktározó anyagok kémiai jellege jobb áttekintést ad a csoportról, ahová a vizsgált minta tartozhat (RICHMOND 2008).

DiLl 1895-ben 15 Chlamydomonas fajt tartott számon, amelyből hat újnak számított. 1927-re a lista 146 fajra gyarapodott, amelyekre Közép-Európában bukkantak. PASCHER (1927) fajleírásait a színtest alakjára és számára, illetve a pirenoidok elhelyezkedésére alapozta. GerLoff (1940) további fajokat határozott meg, ezzel az ismert Chlamydomonas taxonok száma 321-re emelkedett. ETTL átfogó tanulmánya a „Die Gattung Chlamydomonas” (ETTL 1976) már 459 Chlamydomonas fajról tesz említést, miközben a Chloromonas alnemzetséget külön nemzetséggé nyilvánította. A fennmaradó fajokat 9 csoportba sorolta, amelyeket az alnemzetség helyett Hauptgruppen elnevezéssel illetett, de ez utóbbi elnevezés nem kapott hivatalos taxonómiai rangot (Pröschold és SiLva 2007).

A Chlamydomonas nemzetség tagjai egysejtủ szervezetek két egyenlő hosszúságú elülső ostorral, a papilla (kúp alakú nyúlvány) hiányozhat. Fontos határozójegy még a csésze alakú színtest, amely egy vagy több pirenoidot tartalmaz (1. ábra).

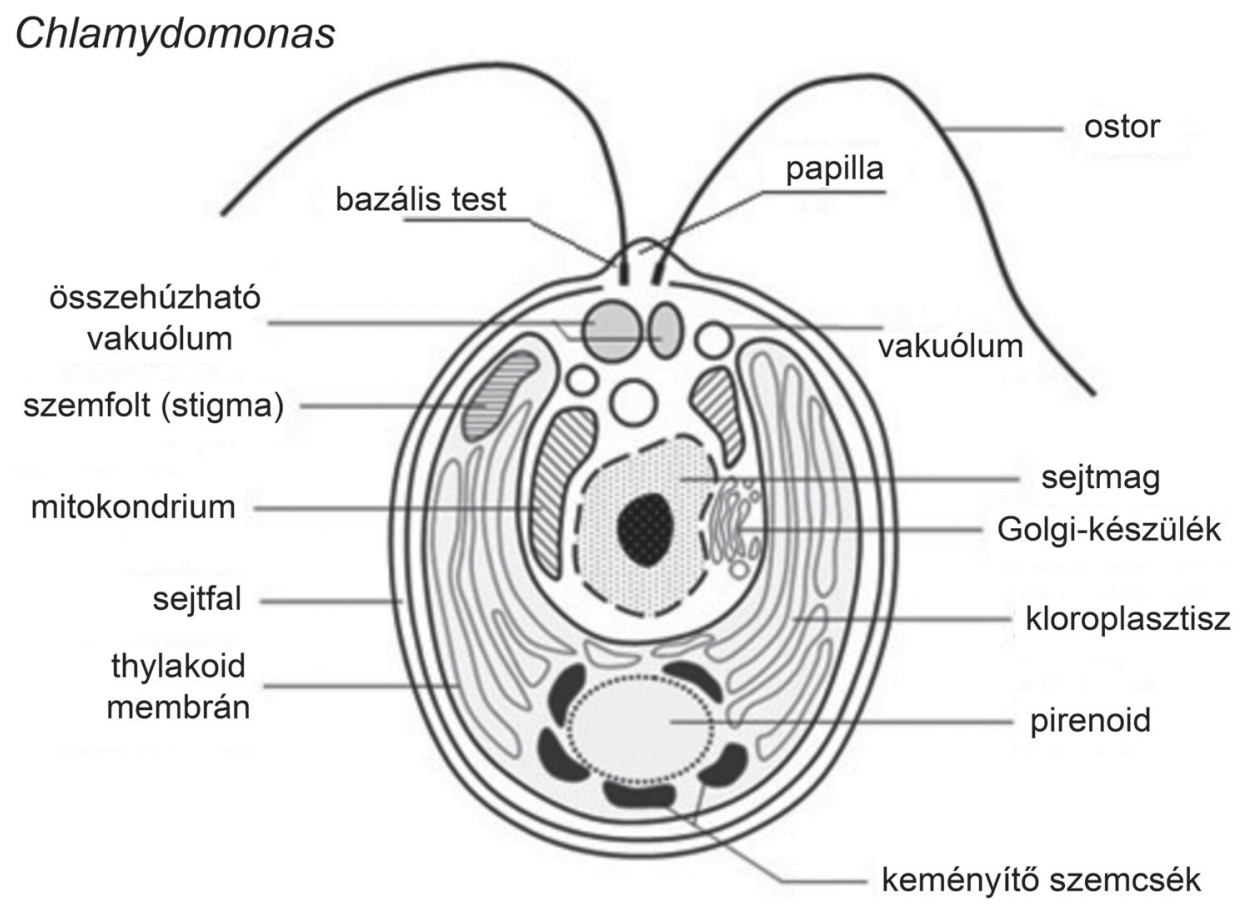

1. ábra. A Chlamydomonas morfológiája (Dent et al. 2001)

Fig. 1. Morphology of Chlamydomonas (Dent et al. 2001) 
A sejtek többnyire 5-10 $\mu \mathrm{m}$ átmérőjűek és körte vagy tojásdad alakúak. A plazmamembránt körülvevő sejtfal glikoprotein-rétegekből áll (STERN et al. 2009). A flagellumok és a bazális testek szerkezetileg és funkcionálisan homológok az állati sejtek csillószőreivel és bazális testeivel, így a Chlamydomonas nemzetség kiváló modellként szolgál e sejtszervek tanulmányozására (PEDERSEN és RosENBAUM 2008). A sejtmag a bazális testek alatt helyezkedik el, míg a sejtek dorzális részét egy nagy, csésze alakú kloroplasztisz alkotja, amely a teljes térfogatnak több mint a felét teszi ki. Az ostorok a sejt méretével megegyező hosszúságúak, vagy annál hoszszabbak, ritkán rövidebbek, csúcsi helyzetűek. A szemfolt általában középen vagy elöl helyezkedik el (Ács és Kiss 2004). A palmella állapot, mint jellemvonás, szintén említést érdemel. Kedvezőtlen körülmények között a Chlamydomonas taxonok elveszítik ostoraikat, és egy zselés anyaggal veszik magukat körül. Ezt követően többszörös osztódással zselés telepet képeznek. A kedvező körülmények beálltával a palmella állapot sejtjei visszanyerik tipikus mozgó alakjukat (SHARMA 1986).

A Chlamydomonas egy hatalmas nemzetség nagyszámú leírt fajjal, de sok közülük valószínüleg nem igazi faj (VUUREN et al. 2006). A nemzetség fajait nehéz azonosítani (HARRIS 1989). A Carteria nemzetség hasonlít a Chlamydomonashoz, de négy ostorral rendelkezik. A Dunaliella szintén hasonlít a Chlamydomonas-hoz, de sejtfala nem erős szerkezetü, és általában a sós tavak rózsaszínes vagy vöröses elszíneződését okozza (BROOK és JoHnson 2002).

\section{A Chlamydomonas taxonok filogenetikai kutatása}

Genetikai markernek tekintünk általában minden olyan tulajdonságot, amely felhasználható egy fajra, populációra, illetve egyedre jellemző DNS-bázissorrend (szekvencia) azonosítására (mark = megjelöl). Ez a tulajdonság lehet morfológiai bélyeg, köztes anyagcseretermék vagy közvetlenül a DNS bizonyos szakaszai. Ez utóbbi az ún. molekuláris marker (HAJósné 1999). A molekuláris markerek alkalmazását a Chlamydomonas nemzetség taxonómiájába az 1990-es években vezették be (LEWIs és McCourt 2004). Tipikus genetikai markerek a nukleáris riboszóma gének, számos kloroplasztisz gén és a mitokondriális gének (NECAs et al. 1986). A riboszómális DNS kis alegységének (SSU rDNS) filogenetikai elemzése például alátámasztotta az ultrastrukturális adatokon alapuló eredeti feltételezést, amely szerint két fő leszármazási vonal van a zöld növények között (FRIEDL 1997). Ez azt jelenti, hogy körülbelül 700 millió évvel ezelőtt a ma élő összes zöld növény közös őse két fö csoportban fejlődött tovább: az egyik a Chlorophyta törzs (idetartoznak a Chlamydomonas fajok is) a másik pedig a Streptophyta törzs (ide pedig egyebek mellett a szárazföldi növények tartoznak). Mindkét csoport egymástól elkülöníthető számos alaktani, élettani és molekuláris jellemző alapján (BECKER 2013). 
A Chlamydomonas reinhardtii genomszekvenciáit 2007-ben publikálták (Merchant et al. 2007), amely még több ismeretet nyújtott az ostoros zöldalgák rendszerével kapcsolatban. A Chlamydomonas nemzetségen elvégzendő genetikai kutatások a közeljövőben is az érdeklődés középpontjában lesznek, mivel betekintést nyújtanak az egysejtű eukarióták rendkívül komplex evolúciójába (Prochnik et al. 2010).

\section{Kihívások a Chlamydomonas taxonok rendszerezésében}

Általánosságban elmondható, hogy a $18 \mathrm{~S}$ rDNS szekvenálás megkérdőjelezte a Chlamydomonas nemzetség morfológiai alapú besorolását. Ugyanakkor számos korábban létrehozott leszármazási vonal határainak felülvizsgálatát is előmozdította (MCCourT 1995). Tehát, míg az egyetlen génen alapuló összehasonlító tanulmányok elfogadhatóak, azok csak részben valósították meg a legfontosabb zöldalgák közötti leszármazási kapcsolatok megismerését (KIRK 2005). Ezért a közeljövőben olyan vizsgálatokat kell elvégezni, amelyek több fajtól származó több gén bevonásával készülnek, így megbízható filogenetikai eredményt kapunk (LELIAERT et al. 2012).

A nemzetségbe tartozó több száz faj mind egysejtủ és két egyenlő hosszúságú ostorral rendelkezik (HARRIs 2009). Ezzel a leírással az a probléma, hogy ezek a jellemzők megtalálhatók sok más taxonban is (PRöschold et al. 2001). A közelmúltban az rRNS szekvenciaanalízisét használták, hogy egyértelmủ monofiletikus taxonokat határozzanak meg a Chlamydomonas nemzetségen belül. A vizsgálat 132 fajt foglalt magában a Chlorophyceae osztályból, és két új nemzetség (Oogamochlamys és Lobochlamys) elkülönítését eredményezte (Pröschold et al. 2001). Fajmeghatározáshoz, a taxonok azonosításához napjainkban a polifázikus (multidiszciplináris) megközelítést említik arany középútként, mivel az a morfológiai, szekvencia-, illetve ökológiai adatok mellett fiziológiai jellemvonásokat is kombinál (SKALOUD 2008). Másik fontos kérdés a vizsgált minták baktériummentessége, ugyanis a DNS-kivonás, majd a sikeres szekvenciaanalízis csak axenikus (idegen mikrobáktól mentes) tenyészetek esetében lehetséges (PATRICio 2013). Az agarlemezes szélesztés célja olyan „vonáskultúra” készítése, melynek eredményeként az inkubálást követően elkülönült telepeket is kapunk. Az ilyen telepek vélhetően egy algasejtből létrejött klóntenyészetek, így azokon már eredményesen elvégezhetőek a molekuláris biológiai vizsgálatok (BLACK 2008).

\section{A polifázikus megközelítés}

Egy nemzetség vagy faj taxonómiai revíziójának legfontosabb feladata, hogy figyelembe vegye az alaktani változatosságot eltérő laboratóriumi és környezeti fel- 
tételek mellett. Éppen ezért javasolt a polifázikus megközelítés használata, amelynek része a fenotípusos sokféleség és a különböző életszakaszok vizsgálata eltérő laboratóriumi feltételek mellett, továbbá a biokémiai és fiziológiai megközelítések, a filogenetikai koncepciók és a fajkoncepciók összehasonlítása, illetve a multi-gén megközelítés. A polifázikus megközelítés használata választ adhat a taxonómiai kérdésekre, legalábbis nemzetség és faji szinten. Természetesen nem minden koncepció és módszer megfelelő taxonómiai vizsgálatokra az összes zöldalga esetében (MATsuo et al. 2005). A polifázikus megközelítés képes fajokat és nemzetségeket megkülönböztetni és meghatározni. Ez egyrészt az eddig leírt fajok számának csökkenéséhez vezet, másrészt több, morfológiailag azonosnak tűnő biológiai faj megkülönböztetéséhez járul hozzá. Például a polifázikus megközelítés használatával a korábban meghatározott megközelítőleg 800 Chlamydomonas faj száma körülbelül 100-150-re csökkenthető (PrösChold és LeliaERT 2007). FAWLEY et al. (2004) rámutattak azonban arra, hogy a zöld mikroalgák biológiai sokfélesége jóval nagyobb a vártnál. Munkájukban 273 törzset izoláltak 93 SSU rDNS szekvenciával négy különböző helyszínről (Észak-Dakota és Minnesota, USA), amelyek közül mindössze négy illeszkedett GenBank-ban közzétett szekvenciákhoz. Ezért ezeket az újonnan izolált törzseket be kell sorolni a rendszerbe a polifázikus megközelítés alkalmazásával. A korábban besorolt élőlényeket szintén (ahogyan és amikor az szükséges) az említett módszerrel újra lehet osztályozni annak érdekében, hogy információt szerezzünk azok aktuális pozíciójáról a mikrobiális világban. Így a jelenlegi technikák lehetővé teszik, hogy a mikrobiológusok megfejtsék a mikrobák között fennálló természetes filogenetikai kapcsolatokat (PRAKASH et al. 2007).

\section{Köszönetnyilvánítás}

Köszönettel tartozom dr. Vörös Lajos professzornak az áttekintés elkészítéséhez nyújtott sokoldalú segítségéért, kritikai észrevételeiért és javaslataiért, amelyek jelentősen hozzájárultak a közlemény minőségének a javításához. A munka a TÁMOP-4.2.2.A-11/1/ KONV-2012-0003 „Mikroalga biotechnológia a fenntartható mezőgazdaságban” projekt keretében készült. A projekt az Európai Unió támogatásával, az Európai Szociális Alap társfinanszírozásával valósul meg.

\section{Irodalomjegyzék}

Ács É., KIss K. T. (szerk.) 2004: Algológiai praktikum. Eötvös Kiadó, Budapest, 361 pp.

BARCLAY W. R., LEWIN R. A. 1985: Microalgal polysaccharide production for the conditioning of agricultural soils. Plant and Soil 88(2): 159-169. http://dx.doi.org/10.1007/BF02182443

Barsanti L., Gualtieri P. 2006: Algae anatomy, biochemistry, and biotechnology. CRC Press, Boca Raton, FL, USA.

BECKeR B. 2013: Snow ball earth and the split of Streptophyta and Chlorophyta. Trends in Plant Science 18(4): 180-183. http://dx.doi.org/10.1016/j.tplants.2012.09.010 
BeLLINGER E. G., SigEe D. C. 2010: Freshwater algae, identification and use as bioindicators. John Wiley \& Sons, West Sussex, UK.

Bertalan I., Esposito D., Torzillo G., Faraloni C., Johanningmeier U., Giardi M. T. 2007: Photosystem II stress tolerance in the unicellular green alga Chlamydomonas reinhardtii under space conditions. Microgravity Science and Technology 19(5): 122-127. http://dx.doi.org/10.1007/BF02919466

Bidigare R. R., Ondrusek M. E., Kennicutt M. C., Iturriaga R. H., Harvey R., Hoham H. W., Mаско S. A. 1993: Evidence for a photoprotective function for secondary carotenoids of snow algae. Journal of Phycology 29(4): 427-434. http://dx.doi.org/10.1111/j.1529-8817

BLACK J. G. 2008: Microbiology: principles and explorations. Wiley.

BLOODGOOD R. A. 1990: Gliding motility and flagellar glycoprotein dynamics in Chlamydomonas. In: Bloodgood R. A. (ed.) Ciliary and flagellar membranes. Plenum Press, New York and London, pp. 91-128.

Brook A. J., Johnson L. R. 2002: Order Zygnemales. In: John D. M., Whitton B. A., Brook A. J. (eds.) The freshwater algal flora of the British Isles. An identification guide to freshwater and terrestrial algae. Cambridge University Press, Cambridge, pp. 479-593.

Buchieim M. A., Turmel M.,Zimmer, E.A., Chapman R.L. 1990: Phylogeny of Chlamydomonas (Chlorophyta) based on cladistic analysis of 18s rRNA sequence data. Journal of Phycology 26(4): 689-699. http://dx.doi.org/10.1111/j.0022-3646.1990.00689.x

Cagnon C., Mirabella B., Nguyen H. M., Beyly-Adriano A., Bouvet B., Cuiné S., Beisson F., Peltier G., Li-Beisson Y. 2013: Development of a forward genetic screen to isolate oil mutants in the green microalga Chlamydomonas reinhardtii. Biotechnology for Biofuels 6: 178. http://dx.doi.org/10.1186/1754-6834-6-178

Chisti Y. 2007: Biodiesel from microalgae. Biotechnology Advances 25(3): 294-306. http://dx.doi.org/10.1016/j.biotechadv.2007.02.001

Deng X., CAI J., LI Y., FeI X. 2014: Expression and knockdown of the PEPC1 gene affect carbon flux in the biosynthesis of triacylglycerols by the green alga Chlamydomonas reinhardtii. Biotechnology Letters 36(11): 2199-2208. http://dx.doi.org/10.1007/s10529-014-1593-3

Dent R., Han M., NiYogi K. K. 2001: Functional genomics of plant photosynthesis in the fast lane using Chlamydomonas reinhardtii. Trends in Plant Science 6(8): 364-371. http://dx.doi.org/10.1016/S1360-1385(01)02018-0

Dill O. 1895: Die Gattung Chlamydomonas und ihre nachsten Verwandten. Jahrbücher für wissenschaftliche Botanik 28: 323-358. pl. 5.

Dolhi J. M., Maxwell D. P., Morgan-Kiss R. M. 2013: Review: the Antarctic Chlamydomonas raudensis: an emerging model for cold adaptation of photosynthesis. Extremophiles 17(5): 711-722. http://dx.doi.org/10.1007/s00792-013-0571-3

Dubini A. 2011: Green energy: biofuel production from Chlamydomonas reinhardtii. The Biochemical Society 33(2): 20-23.

Duval B., Shetty K., Thomas W. H. 2000: Phenolic compounds and antioxidant properties in the snow alga Chlamydomonas nivalis after exposure to UV light. Journal of Applied Phycology 11(6): 559-566. http://dx.doi.org/10.1023/A:1008178208949

Ehrenberg C. G. 1833: Dritter Beitrag zur Erkenntnis großer Organisation in der Richtung des kleinsten Raumes. Abh. Königl. Akad. Wiss. Berlin: 145-336.

Ehrenberg C. G. 1838: Die Infusionsthierchen als vollkommene Organismen. L. Voss, Leipzig.

EтTL H. 1976: Die Gattung Chlamydomonas Ehrenberg (Chlamydomonas und die nächstverwandten Gattungen II). Beih. Nova Hedwigia 60: 1-1122.

Evans R. D., Johansen J. R. 1999: Microbiotic crusts and ecosystem processes. Critical Reviews in Plant Sciences 18(2): 183-225. http://dx.doi.org/10.1080/07352689991309199 
Falchini L., Sparvoli E., Tomaselli L. 1996: Effect of Nostoc (Cyanobacteria) inoculation on the structure and stability of clay soils. Biology and Fertility of Soils 23(3): 346-352. http://dx.doi.org/10.1007/BF00335965

FAN J., ANDRE C., XU C. 2011: A chloroplast pathway for the de novo biosynthesis of triacylglycerol in Chlamydomonas reinhardtii. FEBS Letters 585(12): 1985-1991. http://dx.doi.org/10.1016/j.febslet.2011.05.018

FAWley M. W., FAWLEY K. P., BUCh Heim M. A. 2004: Molecular diversity among communities of freshwater microchlorophytes. Microbial Ecology 48(4): 489-499. http://dx.doi.org/10.1007/s00248-004-0214-4

Francois D. L., Robinson G. G. C. 1988: Indices of triazine toxicity in Chlamydomonas geitleri Ettl. Aquatic Toxicology 16(3): 205-227. http://dx.doi.org/10.1016/0166-445X(90)90038-Q

Frey W. (ed.) 2015: Syllabus of Plant Families - A. Engler's Syllabus der Pflanzenfamilien Part 2/1: Photoautotrophic eukaryotic Algae Glaucocystophyta, Cryptophyta, Dinophyta/Dinozoa, Haptophyta, Heterokontophyta/Ochrophyta, Chlorarachniophyta/Cercozoa, Euglenophyta/Euglenozoa, Chlorophyta, Streptophyta p.p. J. Cramer in der Gebr. Borntraeger Verlagsbuchhandlung, Stuttgart, Germany, 324 pp.

FRIEDL T. 1997: The evolution of the green algae. Plant Systematics and Evolution 11(suppl.): 87-101. http://dx.doi.org/10.1007/978-3-7091-6542-3_4

Funes S., Lars-Gunnar F., González-Halphen D. 2007: Chlamydomonas reinhardtii: the model of choice to study mitochondria from unicellular photosynthetic organisms. Methods in Molecular Biology 372: 137-149. http://dx.doi.org/10.1007/978-1-59745-365-3_10

Gerloff J. 1940: Beiträge zur Kenntnis der Variabilität und Systematik der Gattung Chlamydomonas. Archiv für Protistenkunde 94: 311-502.

Gfeller R. P., Gibbs M. 1984: Fermentative metabolism of Chlamydomonas reinhardtii. Plant Physiology 75(1): 212-218. http://dx.doi.org/10.1104/pp.75.1.212

Ghirardi M. L., Dubini A., Yu J., Maness P. C. 2009: Photobiological hydrogen-producing systems. Chemical Society Reviews 38: 52-61. http://dx.doi.org/10.1039/B718939G

Ghirardi M. L., King P. W., Posewitz M. C., Maness P. C., Fedorov A., Kim K., Cohen J., Schulten K., Seibert M. 2005: Approaches to developing biological $\mathrm{H}_{2}$-photoproducing organisms and processes. Biochemical Society Transactions 33(1): 70-72. http://dx.doi.org/10.1042/BST0330070

Gowans C. S. 1976: Genetics of Chlamydomonas moewusii and Chlamydomonas eugametos. In: LEWIN R. A. (ed.) The genetics of algae. Blackwell Scientific, Oxford, pp. 145-173.

Greenbaum E. 1982: Photosynthetic hydrogen and oxygen production: kinetic studies. Science 215: 291-293. http://dx.doi.org/10.1126/science.215.4530.291

GREENBAUM E. 1988: Energetic efficiency of hydrogen photoevolution by algal water splitting. Biophysical Journal 54(2): 365-368. http://dx.doi.org/10.1016\%2FS0006-3495(88)82968-0

Hajósné Dr. Novák M. 1999: Genetikai variabilitás a növénynemesítésben. Mezőgazda Kiadó, Budapest.

Harris E. H. 1989: The Chlamydomonas sourcebook. Academic Press, San Diego, California.

HARRIS E. H. 2009: The Chlamydomonas sourcebook (second edition). Introduction to Chlamydomonas and its laboratory use, vol. 1. Academic Press, San Diego.

Hu C. X., ZHANG D. L., LiU Y. D. 2004: Research progress on algae of the microbial crusts in arid and semiarid regions. Progress in Natural Science 14(4): 289-295. http://dx.doi.org/10.1080/10020070412331343501

Hu Q., Sommerfeld M., Jarvis E., Ghirardi M., Posewitz M., Seibert M., Dazrins A. 2008 Microalgal triacylglycerols as feedstocks for biofuel production: perspectives and advances. The Plant Journal 54(4): 621-639. http://dx.doi.org/10.1111/j.1365-313X.2008.03492.x 
JÄGER K., BARTóK T., ÖRDÖG V., BARNABÁs B. 2010: Improvement of maize (Zea mays L.) anther culture responses by algae-derived natural substances. South African Journal of Botany 76(3): 511-516. http://dx.doi.org/10.1016/j.sajb.2010.03.009

Kim C. W., Moon M., Park W., Yoo G., Choi Y., Yang J. 2014: Energy-efficient cultivation of Chlamydomonas reinhardtii for lipid accumulation under flashing illumination conditions. Biotechnology and Bioprocess Engineering 19(1): 150-158. http://dx.doi.org/10.1007/s12257-013-0468-0

KIRK D. L. 2005: A twelve-step program for evolving multicellularity and a division of labor. Bioessays 27(3): 299-310. http://dx.doi.org/10.1002/bies.20197

Kol E., Flint E. A. 1968: Algae in green ice from the Balleny Islands, Antarctica. New Zealand Journal of Botany 6(3): 249-261. http://dx.doi.org/10.1080/0028825X.1968.10428810

Leliaert F., Smith D. R., Moreau H., Herron M. D., Verbruggen H., Delwiche C. F., De Clerck O. 2012: Phylogeny and molecular evolution of the green algae. Critical Reviews in Plant Sciences 31(1): 1-46. http://dx.doi.org/10.1080/07352689.2011.615705

Lemieux B., Turmel M., Lemieux C. 1985: Chloroplast DNA variation in Chlamydomonas and its potential application to the systematics of this genus. BioSystems 18(3-4): 293-298. http://dx.doi.org/10.1016/0303-2647(85)90029-2

LEÓN R., GALVÁN F. 1997: Analysis of effective light in different photobioreactors: its influence on growth, photosynthetic activity and glycerol production by the freshwater green alga Chlamydomonas reinhardtii. World Journal of Microbiology and Biotechnology 13(2): 237-239. http://dx.doi.org/10.1023/A:1018506317991

Lewis A. L., McCourt R. M. 2004: Green algae and the origin of land plants. American Journal of Botany 91(10): 1535-1556. http://dx.doi.org/10.3732/ajb.91.10.1535

Manuel A., Beligni M., Elder J., Siefker D., Tran M., Webber A., McDonald T., MayFIELD S. 2007: Robust expression of a bioactive mammalian protein in Chlamydomonas chloroplast. Plant Biotechnology Journal 5(3): 402-412. http://dx.doi.org/10.1111/j.1467-7652.2007.00249.x

Matsuo Y., Imagawa H., Nishizawa M., Shizuri Y. 2005: Isolation of an algal morphogenesis inducer from a marine bacterium. Science 307: 1598. http://dx.doi.org/10.1126/science.1105486

MAYField S., FrankLin S. 2005: Expression of human antibodies in eukaryotic micro-algae. Vaccine 23(15): 1828-1832. http://dx.doi.org/10.1016/j.vaccine.2004.11.013

McCourt R. M. 1995: Green algal phylogeny. Trends in Ecology and Evolution 10(4):159-163. http://dx.doi.org/10.1016/S0169-5347(00)89027-8

Melis A., Zhang L., Forestier M., Hirardi M. L., Seibert M. 2000: Sustained photobiological hydrogen gas production upon reversible inactivation of oxygen evolution in the green alga Chlamydomonas reinhardtii. Plant Physiology 122(1): 127-136.

http://dx.doi.org/10.1104/pp.122.1.127

Merchant S. S., Prochnik S. E., Vallon O., Harris E. H., Karpowicz S. J., Witman G. B. et al. 2007: The Chlamydomonas genome reveals the evolution of key animal and plant functions. Science 318: 245-250. http://dx.doi.org/10.1126/science.1143609

Metting B. 1987: Dynamics of wet and dry aggregate stability from a three-year microalgal soil conditioning experiment in the field. Soil Science 143(2): 139-143. http://dx.doi.org/10.1097/00010694-198702000-00009

Metting B. 1988: Micro-algae in agriculture. In: Borowitzka M. A., Borowitzka L. J. (eds.) Microalgal biotechnology. Cambridge University Press, Cambridge, pp. 288-304.

Metting B., Rayburn W. R. 1983: The influence of a microalgal conditioner on selected Washington soils: an empirical study. Soil Science Society of America Journal 47(4): 682-685. http://dx.doi.org/10.2136/sssaj1983.03615995004700040015x 
Misurcova L., Skrovankova S., Samek D., Ambrozova J., Machu L. 2012: Health benefits of algal polysaccharides in human nutrition. Advances in Food and Nutrition Research 66: 75-145. http://dx.doi.org/10.1016/b978-0-12-394597-6.00003-3

Mussgnug J. H., Klassen V., Schlüter A., Kruse O. 2010: Microalgae as a substrates for fermentative biogas production in a combined biorefinery concept. Journal of Biotechnology 150(1): 51-56. http://dx.doi.org/10.1016/j.jbiotec.2010.07.030

Necas J., Tetik K., Sule K J. 1986: Mutation process induced by MNNG in different phases of the cell cycle in Chlamydomonas geitleri VI. Dependence of the induction of mutagenesis on the mutagen dose in the course of the cell cycle. Archiv für Hydrobiologie, Suppl. 44: 393-404.

Norton T. A., Melkonian M., Andersen R. A. 1996: Algal biodiversity. Phycologia 35(4): 308-326. http://dx.doi.org/10.2216/i0031-8884-35-4-308.1

Ördög V., Pocsai K., Gergely I., Bálint P., Németh L., Molnár Z. 2006: Microalgae in plant production and protection. 3rd Symposium on Microalgae and Seaweed Products in Agriculture, Mosonmagyaróvár (Hungary), 21-23 June, p. 1.

PAinter T. 1993: Carbohydrate polymers in desert reclamation: the potential of microalgal biofertilizers. Carbohydrate Polymers 20(2): 77-86. http://dx.doi.org/10.1016/0144-8617(93)90081-E

PAscher A. 1927: Eine Chrysomonade mit gestielten und verweigten Kolonien. Archiv für Protistenkunde 57: 319-330.

PAtricio A. L. 2013: Isolation, characterization and identification of microalgae from the Red Sea. Thesis. King Abdullah University of Science and Technology, Thuwal, Kingdom of Saudi Arabia.

Pedersen L. B., Rosenbaum J. L. 2008: Intraflagellar transport (IFT): role in ciliary assembly, resorption and signalling. Current Topics in Developmental Biology 85: 23-61. http://dx.doi.org/10.1016/S0070-2153(08)00802-8

Prakash J. W., Marimuthu J., Jeeva S. 2011: Antimicrobial activity of certain fresh water microalgae from Thamirabarani River, Tamil Nadu, South India. Asian Pacific Journal of Tropical Biomedicine: 1(2): S170-S173. http://dx.doi.org/10.1016/S2221-1691(11)60149-4

Prakash O., Verma M., Sharma P., Kumar M., Kumari K., Singh A., Kumari H., Jit S., Gupta S. K., Khanna M., LAL R. 2007: Polyphasic approach of bacterial classification - an overview of recent advances. Indian Journal of Microbiology 47(2): 98-108. http://dx.doi.org/10.1007/s12088-007-0022-x

Prochnik S. E., Umen J., Nedelcu A. M., Hallmann A., Miller S. M., Nishii I. et al. 2010: Genomic analysis of organismal complexity in the multicellular green alga Volvox carteri. Science 329: 223-226. http://dx.doi.org/10.1126/science.1188800

Pröschold T., Marina B., Schlösserb U. G., Melkoniana M. 2001: Molecular phylogeny and taxonomic revision of Chlamydomonas (Chlorophyta). I. Emendation of Chlamydomonas Ehrenberg and Chloromonas Gobi, and description of Oogamochlamys gen. nov. and Lobochlamys gen. nov. Protist 152(4): 265-300. http://dx.doi.org/10.1078/1434-4610-00068

Pröschold T., Leliaert F. 2007: Systematics of the green algae: conflict of classic and modern approaches. In: Brodie J., Lewis J., (eds.) Unravelling the algae: The past, present, and future of algal systematics, CRC Press, Boca Raton, FL, pp. 123-153. http://dx.doi.org/10.1201/9780849379901.ch7

Pröschold T., Silva, P. C. 2007: Proposal to change the listed type of Chlamydomonas Ehrenb., nom. cons. (Chlorophyta). Taxon 56(2): 595-596.

Pulz O., Gross W. 2004: Valuable products from biotechnology of microalgae. Applied Microbiology and Biotechnology 65(6): 635-648. http://dx.doi.org/10.1007/s00253-004-1647-x

Remias D., Lutz U., Lutz C. 2010: Photosynthesis, pigments and ultrastructure of the alpine snow alga Chlamydomonas nivalis. European Journal of Phycology 40(3): 259-268. http://dx.doi.org/10.1080/09670260500202148 
Richmond A. 2008: Handbook of microalgal culture: biotechnology and applied phycology. Wiley, Blackwell.

Rodolfi L., Zittelli C. G., Bassi N., Padovani G., Biondi N., Bonini G., Tredici M. R. 2009: Microalgae for oil: strain selection, induction of lipid synthesis and outdoor mass cultivation in a low-cost photobioreactor. Biotechnology and Bioengineering 102(1): 100-112. http://dx.doi.org/10.1002/bit.22033

Sharma O. P. 1986: Textbook of Algae. Tata McGraw-Hill, New Delhi.

SKALOUd P. 2008: Polyphasic approaches in the taxonomy of green aerophytic algae. Ph. D. thesis. Charles University in Prague, Faculty of Science, Department of Botany.

Slaninová M., Nagyová B., Gálová E., Hendrychová J., Bišová K., Zachleder V., VlčeK D. 2003: The alga Chlamydomonas reinhardtii UVS11 gene is responsible for cell division delay and temporal decrease in histone $\mathrm{H} 1$ kinase activity caused by UV irradiation. DNA Repair 2(6): 737-750. http://dx.doi.org/10.1016/s1568-7864(03)00047-8

Solís R. A. R., Echeverría S. P., VAlencia V. A. H. 2011: La microalga verde Chlamydomonas reinhardtii: nueva alternativa para la producción de proteínas recombinantes de interés médico. Revista Ciencia, Octubre-Deciembre 2011, pp. 2-9.

Spolaore P., Joannis-Cassan C., Duran E., Isambert A. 2006: Commercial applications of microalgae. Journal of Bioscience and Bioengineering 101(2): 87-96. http://dx.doi.org/10.1263/jbb.101.87

Stern D. B., Witman G., Harris E. H. (eds.) 2009: The Chlamydomonas sourcebook. Second edition. Academic Press, Oxford.

Stirk W. A., Ördög V., Novák O., Rolcik J., Strnad M., Bálint P., van Staden J. 2013a: Auxin and cytokinin relationships in 24 microalgal strains. Journal of Phycology 49(3): 459-467. http://dx.doi.org/10.1111/jpy.12061

Stirk W. A., Bálint P., Tarkowská D., Novák O., Strnad M., Ördög V., van Staden J. 2013b: Hormone profiles in microalgae: gibberellins and brassinosteroids. Plant Physiology and Biochemistry 70: 348-353. http://dx.doi.org/10.1016/j.plaphy.2013.05.037

Takeda T., Miyao K., Tamoi M., Kanaboshi H., Miyasaka H., Shigeoka S. 2003: Molecular characterization of glutathione peroxidase-like protein in halotolerant Chlamydomonas sp. W80. Physiologia Plantarum 117(4): 467-475. http://dx.doi.org/10.1034/j.1399-3054.2003.00075.x

TAmoi M., Nagaoka M., Shigeoka S. 2005: Immunological properties of sedoheptulose-1,7bisphosphatase from Chlamydomonas sp. W80. Bioscience, Biotechnology and Biochemistry 69(4): 848-851. http://dx.doi.org/10.1271/bbb.69.848

TANAKA S., IKEDA K., MIYASAKA H. 2004: Isolation of a new member of group 3 late embryogenesis abundant protein gene from a halotolerant green alga by a functional expression screening with cyanobacterial cells. FEMS Microbiology Letters 236: 41-45.

http://dx.doi.org/10.1016/s0378-1097(04)00357-x

Tetali S. D., Mitra M., Melis A. 2007: Development of the light-harvesting chlorophyll antenna in the green alga Chlamydomonas reinhardtii is regulated by the novel Tla1 gene. Planta 225(4): 813-829. http://dx.doi.org/10.1007/s00425-006-0392-z

Tran M., Zhon B., Petterson P., González M., Mayfield S. 2009: Synthesis and assembly of a full-length human monoclonal antibody in algal chloroplasts. Biotechnology and Bioengineering 104(4): 663-673. http://dx.doi.org/10.1002/bit.22446

Ugwu C. U., Aoyagi H., Uchiyama H. 2008: Photobioreactors for mass cultivation of algae. Bioresource Technology 99(10): 4021-4028. http://dx.doi.org/10.1016/j.biortech.2007.01.046

UMEN J. G. 2011: Evolution of sex and mating loci: an expanded view from Volvocine algae. Current Opinion in Microbiology 14(6): 634-641. http://dx.doi.org/10.1016/j.mib.2011.10.005 
VanWinkle-Swift K., Baron K., McNamara A., Minke P., Burrascano C., Maddock J. 1998: The Chlamydomonas zygospore: mutant strains of Chlamydomonas monoica blocked in zygospore morphogenesis comprise 46 complementation groups. Genetics 148(1): 131-137.

Visviki I., Palladino J. 2001: Growth and cytology of Chlamydomonas acidophila under acidic stress. Bulletin of Environmental Contamination and Toxicology 66(5): 623-630. http://dx.doi.org/10.1007/s001280054

Visviki I., SANTikul D. 2000: The pH tolerance of Chlamydomonas applanata (Volvocales, Chlorophyta). Archives of Environmental Contamination and Toxicology 38(2): 147-151. http://dx.doi.org/10.1007/s002449910018

Vuuren S. J., Taylor J., van Ginkel C., Gerber A. 2006: Easy identification of the most common freshwater algae. North-West University, Potchefstroom.

WirTH R. 2014: Biogáz termelő mikroorganizmus közösségek vizsgálata metagenomikai megközelítéssel. Doktori értekezés. SZTE és MTA-SZBK.

Zenova G. M., Shtina E. A., Dedysh S. N., Glagoleva O. B., Likhacheva A. A., Gracheva T. A. 1995: Ecological relations of algae in biocenoses. Mikrobiologiya 64: 121-133.

Zhang P., Liu S., Cong B., Wu G., Liu C., Lin X., Shen J., Huang X. 2011: A novel omega-3 fatty acid desaturase involved in acclimation processes of polar condition from Antarctic ice algae Chlamydomonas sp. ICE-L. Marine Biotechnology 13(3): 393-401. http://dx.doi.org/10.1007/s10126-010-9309-8

ZIMMERMAN W. J. 1992: Microalgal biotechnology and applications in agriculture. In: MetTING F. B. (ed.) Soil microbial ecology. Marcel Dekker, New York, pp. 457-479.

\title{
REVIEW
}

\section{The role of Chlamydomonas green alga genus in biotechnology and its place in the system of green algae}

\author{
Sz. KATONA ${ }^{1}$, Z. MOLNÁR ${ }^{1}$ and V. ÖRDÖG ${ }^{1,2}$ \\ ${ }^{1}$ Institute of Plant Biology, Faculty of Agricultural and Food Sciences, University of West \\ Hungary, H-9200 Mosonmagyaróvár, Lucsony str. 15-17; szabina.katona@gmail.com \\ ${ }^{2}$ University of KwaZulu-Natal, School of Biological Sciences, Pietermaritzburg Campus, \\ 3209 Scottsville, Private Bag X 01, South African Republic
}

Accepted: 25 February 2016

Key words: biotechnology, Chlamydomonas, green algae, phylogenetics, polyphasic approach, taxonomy.

Chlamydomonas is one of the biggest green algal genera with more than 800 described species. Approximately 400 strains are available in collections and applicable for research purposes. Referring to the versatility of genus Chlamydomonas, it is applied on scientific fields such as genetics, photosynthesis research, UV- 
resistance issues, possibilities of biogas and biodiesel production, hormone research, agriculture and medicine. The green alga genus Chlamydomonas is traditionally classified according to morphological characteristics in the vegetative stage of the life cycle. Essential features of the genus are the two anterior flagella of equal length and the single chloroplast containing one or more pyrenoids. Since the 1990s, the use of molecular markers for phylogenetic analysis demonstrated that the morphological approach is appropriate neither for most green algae, nor for the genus Chlamydomonas. Most green alga genera are polyphyletic, so their status and species number require further revision. The latest trend is the polyphasic approach which combines different methods like morphology, cytology, ultrastructural and molecular biological studies. Morphologists on the side of traditional taxonomy register more than 800 Chlamydomonas species, however this amount will likely decrease to 100-150 Chlamydomonas species by using a polyphasic approach. 